\title{
The weevil Dynamis borassi (Coleoptera: Curculionidae: Dryophthorinae) associated with native palms in forests and disturbed areas in Buenaventura, Colombia
}

\author{
El picudo Dynamis borassi (Coleoptera: Curculionidae: Dryophthorinae) asociado a \\ palmas nativas en bosques y zonas perturbadas en Buenaventura, Colombia
}

\author{
MARIA ALEJANDRA BAUTISTA-GIRALDO ${ }^{1}$; INGE ARMBRECHT'; \\ AYMER ANDRÉS VÁSQUEZ-ORDOÑEZ ${ }^{3}$
}

\begin{abstract}
${ }^{1}$ Biologist. Department in Biological Sciences, Universidad de Caldas, Manizales, Caldas, Colombia, alejandra.bautista.giraldo@gmail.com, https://orcid.org/0000-0003-2669-2386. ${ }^{2} \mathrm{Ph}$. D. Titular Professor, Biology Department, Universidad del Valle, Santiago de Cali, Valle del Cauca, Colombia, inge.armbrecht@correounivalle.edu.co, https://orcid.org/0000-0003-0574-2559. ${ }^{3}$ B. Sc. Ph. D. candidate in Biology-Sciences, Universidad del Valle, Santiago de Cali, Valle del Cauca, Colombia, aymer.vasquez@correounivalle.edu.co, https://orcid.org/0000-0002-4970-9067.
\end{abstract}

\section{Corresponding author}

Maria Alejandra Bautista-Giraldo. Biologist. Department in Biological Sciences, Universidad de Caldas, Manizales, Caldas, Colombia, alejandra.bautista.giraldo@gmail.com

\section{Suggested citation}

BAUTISTA-GIRALDO, M. A.; ARMBRECHT, I.; VÁSQUEZ-ORDOÑEZ, A. A. 2020 The weevil Dynamis borassi (Coleoptera: Curculionidae: Dryophthorinae) associated with native palms in forests and disturbed areas in Buenaventura, Colombia. Revista Colombiana de Entomología 46 (2): e7721. https://doi.org/10.25100/socolen.v46i2.7721

Received: 30-Mar-2019

Accepted: 23-Mar-2020

Published: 26-Dic-2020

Revista Colombiana de Entomología ISSN (Print): 0120-0488

ISSN (On Line): 2665-4385

https://revistacolombianaentomologia.univalle.edu.co

Open access

(c) (1) (2)(2) BY-NC-SA 4.0

Publishers: Sociedad Colombiana de Entomología SOCOLEN (Bogotá, D. C., Colombia) https://www.socolen.org.co

Universidad del Valle (Cali, Colombia)

https://www.univalle.edu.co

(C) 2020 Sociedad Colombiana de Entomología -

SOCOLEN y Universidad del Valle
Abstract: Deforestation produces homogeneous agricultural environments creating an imbalance between herbivores and their hosts. Since 2010, there has been a phytosanitary crisis in the peach palm (or chontaduro), Bactris gasipaes in the Colombian Pacific Region which can be attributed to two species of palm weevils: Rhynchophorus palmarum and Dynamis borassi. It has been proposed that deforestation of native palms, used by these weevils, induces these to find new resources in the peach palm. This study examined the association of these two weevils with native palms near chontaduro crops and how this occurs in two types of habitats. Six secondary forests and six anthropogenically disturbed areas were visited in third administrative division: "corregimientos" 1 and 2 (Zone A) and 7 and 8 (Zone B) in the municipality of Buenaventura. Three $50 \times 100 \mathrm{~m}$ plots were designated in each zone, all palms with damage being recorded; the sampling was also complemented with a free sample. Twelve palm species distributed into one subfamily and nine genera were identified. A total of 271 unopened inflorescences were examined in Zone A and 501 in Zone B. Only evidence of damage was found in individuals of the "milpesos" palm (Oenocarpus bataua), an economically exploitable species. The proportion of palms affected in terms of habitat was significantly higher in the disturbed habitat. This is the first record that quantifies a high percentage of association between $D$. borassi and the "milpesos" palm in the Colombian Pacific Region, a phenomenon that could be explained by agroecological hypotheses.

Keywords: Secondary forest, palm inflorescences, tropical deforestation, palm borers, disturbed zones, chontaduro, Coleoptera, Bactris gasipaes, Rhynchophorus palmarum, Dynamis borassi.

Resumen: La deforestación produce ambientes agrícolas homogéneos y puede generar desequilibrios entre los herbívoros y sus hospederos. Desde 2010, ha ocurrido una crisis fitosanitaria en el cultivo de la palma de chontaduro (Bactris gasipaes) en el Pacífico colombiano, atribuida a los picudos Rhynchophorus palmarum y Dynamis borassi. Se ha planteado que la deforestación de palmas nativas utilizadas por estos picudos, hace que busquen nuevos recursos y los encuentran en el chontaduro. Esta investigación examinó la asociación de estos picudos con palmas nativas cercanas a cultivos de chontaduro, y cómo se da en dos tipos de hábitats. Se visitaron seis bosques secundarios y áreas antropogénicamente intervenidas en los corregimientos 1 y 2 (zona A), y 7 y 8 (zona B) de Buenaventura. En cada una se delimitaron tres parcelas de 100 x $50 \mathrm{~m}$ y se registraron todas las palmas con daño, además se complementó con un muestreo libre. Se identificaron doce especies de palmas distribuidas en una subfamilia y nueve géneros. Se examinaron 271 inflorescencias sin abrir en la zona A y 501 en B. Solo se evidenció daño en individuos de la palma "milpesos" (Oenocarpus bataua), especie económicamente explotable. La proporción de palmas afectadas en términos de hábitat fue significativamente mayor en el área intervenida. Este es el primer registro que cuantifica un alto porcentaje de asociación entre $D$. borassi y la palma "milpesos", fenómeno que podría ser explicado por hipótesis agroecológicas.

Palabras clave: Bosque secundario, inflorescencias de palmas, deforestación tropical, barrenadores de palmas, zonas perturbadas, chontaduro, Coleoptera, Bactris gasipaes, Rhynchophorus palmarum, Dynamis borassi. 


\section{Introduction}

Anthropogenic activities in terrestrial landscapes transform heterogeneous agricultural environments into homogeneous ones (Perfecto et al. 2009). This homogenization can lead to rapid production improvement; however, in the long term, it can produce negative consequences when important ecological functions that regulate pests are lost (Lindgren et al. 2018). For instance, the loss of plant architecture, that supports natural enemies or physically and chemically barriers from complex vegetation, directly inhibits pest attack (Altieri 1992).

An ecological consequence of habitat transformation by humans is that some herbivore populations increase as a response to resource homogenization, thus giving rise to economic problems for a crop (Armbrecht 2016). It has been suggested that decreased diversity could result in a greater abundance of focal host species (Pagán et al. 2012). Furthermore, greater plant diversity in agroecosystems has been related to an increase in insect diversity which, in turn, can result in less damage by insect herbivory (Letourneau et al. 2011).

Insect pests, especially species those with a limited host range, have greater difficulty in locating and remaining on their host plants in small, scattered crops rather than on large, dense crops (Root 1973). These changes in behavior may be due to the chemical and visual interference used for locating the host plant or to the quality of microhabitats (Andow 1991). In agroecology, the pattern just described is known as the resource concentration hypothesis, which leads to the prediction that crop herbivory will tend to decrease in more biodiverse contexts (Vandermeer 1989; Armbrecht 2016). Recent empirical evidence demonstrates that both the presence of forests and the design of diversified agricultural systems guarantee beneficial inter-species interactions, better weed suppression and the disruption of the life cycle of pests (Cong et al. 2015; Palomo-Campesino et al. 2018).

The chontaduro, "pejibaye" or peach palm (Bactris gasipaes Kunth, 1816; Arecaceae) was domesticated in pre-Columbian times by the Amerindians in the humid lowland neotropics. At present, it is widely cultivated outside of its original area (Ordoñez-Santos et al. 2015) occupying most of the neotropics (Mora-Urpí et al. 1997) from Honduras to Bolivia (along the Atlantic Coast of Central and South America to Brazil, and along the Pacific Coast from Costa Rica to the extreme south of Peru). Brazil, Colombia, Costa Rica, and Peru are the greatest producers (Clement et al. 2004). In Colombia, the peach palm is best represented in the Pacific and Amazon Regions (Godoy et al. 2007).

In 2010, a phytosanitary crisis was detected in peach palm production areas on the Colombian Pacific Coast. The damage was characterized by the toppling of palm crowns, causing the death of at least 253.000 plants (ICA 2015) This has been widely attributed to the palm weevil, Rhynchophorus palmarum L., 1758 (Coleoptera: Curculionidae). However, the presence of another very similar weevil, Dynamis borassi (Fabricius, 1801) (Coleoptera: Curculionidae), has also been recorded in chontaduro (Pardo-Locarno et al. 2016). As pointed out by farmers, this phytosanitary crisis coincided with the indiscriminate removal of native palms in different chontaduro production areas (Löhr and Vasquez-Ordóñez, pers. comm, November and December 2017), which are used for building material, food, and other purposes (Bernal and Galeano 2013). All of this has exerted a negative effect on palm diversity and population dynamics (Navarro 2015).
Therefore, the phenomenon has probably important changes in forest dynamics since these palms are key components of tropical rain forest structure (Benchimol et al. 2017).

Damage promoted by $D$. borassi has been recorded in Astrocaryum chonta Mart. (1844) and A. carnosum F. Kahn and B. Millán (1992) in Peru (Couturier et al. 2000); Euterpe oleracea Mart. (1824) and Oenocarpus minor Mart. (1823) in Brazil (Couturier et al. 1998a, 1998b, 2000; Beserra et al. 2006); Cocos nucifera L. (1753) in Ecuador (Gerber et al. 1990) and Syagrus schizophylla (Mart.) Glassman (1968) and S. vagans (Bondar) A.D. Hawkes (1952) (Couturier et al. 1998a) in Brazil. In Colombia, this insect is associated with coconut palms (Mora-Urpi et al. 1997) and, specifically in Buenaventura municipality, with peach palm or chontaduro (Pardo-Locarno et al. 2005, 2016). Therefore, in this study we expected to find inflorescences of different species of native palms (besides chontaduro) being attacked by these weevils.

Details of the interaction between the Oenocarpus bataua Mart. (1823) or "milpesos" palm and D. borassi are unknown and how this interaction may vary in different types of habitats has not been evaluated. Therefore, the present study aimed to determine which species of native palms are used by $D$. borassi and the incidence of these weevils on native palms in two types of habitats: secondary forest and disturbed areas in two zones in the municipality of Buenaventura, Valle del Cauca, Colombia.

\section{Materials and methods}

Study area. The samplings were carried out in third administrative division: "Corregimientos" 1 and 2 (hereafter Zone A) and 7 and 8 (hereafter Zone B) in the municipality of Buenaventura, Valle del Cauca (Alcaldía Distrital de Buenaventura 2015). In the Bajo Calima area, near Zone A, average annual temperature is $26.5^{\circ} \mathrm{C}$, relative humidity is $90 \%$ and precipitation is ca. 7,500 $\mathrm{mm}$ (Bocanegra-Gonzaléz et al. 2015). The Anchicaya River Basin, near the Zone B, has an average annual temperature of $26^{\circ} \mathrm{C}$, relative humidity of $86 \%$ (Angulo 2012) and annual precipitation between 4,000 and $8,000 \mathrm{~mm}$ (Pardo-Locarno et al. 2016).

Sampling sites located in Zone A were studied between May 30 and June 8, 2018 whereas the sites in Zone B were studied between June 26 and July 7, 2018. The geographical coordinates and names of all the sampling sites are listed in Table 1. In each zone, seven sampling points were identified: three were classified as secondary forest (Habitat 1), three as anthropogenically disturbed areas (Habitat 2) and one was a free sampling point (see below). The secondary forest had at least four vertical vegetation layers and signs of healthy regeneration such as seedlings, herbaceous vegetation, and adult trees with overlapping canopies. The soil in the forest had abundant decomposing leaf litter and lacked dominant grasses. The criterion for selecting the "forest" habitat was the presence of arboreal tree structure and closed canopy. The disturbed areas were characterized by having very exposed palms, no canopy cover and, on many occasions, clearings at ground level. Ground cover was mainly characterized by the presence of one species of fern, Dicranopteris sp. (Gleicheniaceae), which normally grows in open or deforested tropical soils (Zhao et al. 2012), or pastureland with little vegetation (Fig. 1). Finally, a free sampling was carried out in the two Zones (A and B) by following dirt roads in primary succession areas for approximately $3 \mathrm{~h}$ (time was not standardized). 
Table 1. Geographic location of Zone A ("Corregimientos" 1 and 2) and Zone B ("Corregimientos" 7 and 8) sampling sites in the municipality of Buenaventura, Valle del Cauca, Colombia.

\begin{tabular}{|c|c|}
\hline Name of location (Type of habitat) & Coordinates \\
\hline \multicolumn{2}{|l|}{ Zone A } \\
\hline "El Guineo"- Stations of "Universidad del Tolima" (disturbed habitat) & $3^{\circ} 57^{\prime} 07.32^{\prime \prime} \mathrm{N} 76^{\circ} 59^{\prime} 16.21^{\prime \prime} \mathrm{W}$ \\
\hline "Tatabro" (Km 15) (disturbed habitat) & $3^{\circ} 57^{\prime} 33.72^{\prime \prime} \mathrm{N} 77^{\circ} 00^{\prime} 23.14^{\prime \prime} \mathrm{W}$ \\
\hline "El Vivero" (disturbed habitat) & $3^{\circ} 56^{\prime} 26.26^{\prime \prime} \mathrm{N} 76^{\circ} 59^{\prime} 06.05^{\prime \prime} \mathrm{W}$ \\
\hline "Guineo" (secondary forest habitat) & $3^{\circ} 58^{\prime} 27.30^{\prime} \mathrm{N} 77^{\circ} 00^{\prime} 12.38^{\prime \prime} \mathrm{W}$ \\
\hline "Tatabro" (Km 15) (secondary forest habitat) & $3^{\circ} 57^{\prime} 30.46^{\prime \prime} \mathrm{N} 77^{\circ} 00^{\prime} 30.01^{\prime \prime} \mathrm{W}$ \\
\hline "El Vivero" (secondary forest habitat) & $3^{\circ} 56^{\prime} 07.69^{\prime} \mathrm{N} 76^{\circ} 59^{\prime} 17.14$ ” W \\
\hline "Brisas" (free sampling) & $3^{\circ} 57^{\prime} 31.22^{\prime \prime} \mathrm{N} 77^{\circ} 00^{\prime} 13.64^{\prime \prime} \mathrm{W}$ \\
\hline \multicolumn{2}{|l|}{ Zone B } \\
\hline "Alto Potedó" (disturbed habitat) & $3^{\circ} 45^{\prime} 48.38^{\prime \prime} \mathrm{N} 76^{\circ} 57^{\prime} 49.49^{\prime \prime} \mathrm{W}$ \\
\hline "Bogotá" (disturbed habitat) & $3^{\circ} 46^{\prime} 06.70^{\prime} \mathrm{N} 76^{\circ} 58^{\prime} 04.73^{\prime \prime} \mathrm{W}$ \\
\hline "San Marcos" (disturbed habitat) & $3^{\circ} 42^{\prime} 47.83^{\prime \prime} \mathrm{N} 76^{\circ} 57^{\prime} 31.89^{\prime \prime} \mathrm{W}$ \\
\hline "Bartolo" (secondary forest habitat) & $3^{\circ} 41^{\prime} 30.40^{\prime} \mathrm{N} 76^{\circ} 57^{\prime} 59.84^{\prime \prime} \mathrm{W}$ \\
\hline "El Colegial" (secondary forest habitat) & $3^{\circ} 41^{\prime} 06.08^{\prime \prime} \mathrm{N} 76^{\circ} 57^{\prime} 13.48^{\prime \prime} \mathrm{W}$ \\
\hline "Chaverra" (secondary forest habitat) & $3^{\circ} 41^{\prime} 47.41^{\prime \prime} \mathrm{N} 76^{\circ} 57^{\prime} 49.59^{\prime \prime} \mathrm{W}$ \\
\hline "Potedó" (free sampling) & $3^{\circ} 47^{\prime} 39.58^{\prime \prime} \mathrm{N} 76^{\circ} 59^{\prime} 20.18^{\prime \prime} \mathrm{W}$ \\
\hline
\end{tabular}

Sampling design. At each of the sites (except those for free sampling), three $50 \times 100 \mathrm{~m}$ plots were measured for a total of 36 plots in the entire study. Each plot was divided into four $25 \times 50 \mathrm{~m}$ cells (Fig. 2). Distance between plots was a least $20 \mathrm{~m}$. In each of the plots, the species of palms were identified and evidence of damage to inflorescences by borers was carefully searched for using binoculars. All sites evaluated were within a range of 500-1,000 m from the peach palm crops.

Free sampling was focused on specimens of the "milpesos" palm in order to increase the number of captured weevils and document the damage they cause to this specific species of interest. Free sampling time was five hours for Zone A and one hour for Zone B. Although time could not be standardized due to access logistics and security issues, the shorter sampling period in the second zone was partially rectified by having two researchers conduct the evaluation, both with more experience than in Zone A.

Damaged bracts (unopened inflorescences) were collected with the aid of a tree pruner (the maximum height of the palms from which the bracts were obtained was $15 \mathrm{~m}$ ) when tree height and slope of terrain permitted. These were subsequently dissected in search of insects. Recovered adult weevils were preserved in $96 \%$ ethanol. Following the Stehr (1987) protocol, the larvae were boiled (in $100^{\circ} \mathrm{C}$ water) and placed in labeled vials with $96 \%$ ethanol. The pupae were extracted from the palm inflorescences along with their cocoon and taken to the laboratory at the Universidad del Valle in Cali, Colombia, where they were raised until the emergence of imagos.

Sample processing. All palms were identified according to Galeano and Bernal (2010). Samples of vegetative and/or reproductive parts were collected when further examination was required for reliable identification. Voucher specimens were deposited at the "Luis Sigifredo Espinal Tascón Herbarium", Universidad del Valle (CUVC), under the following codes: Bactris coloradonis L. H. Bailey (1933) (CUVC-67962 to CUVC-67965), Euterpe precatoria Mart. (1842). (CUVC67955 to CUVC-67958), Manicaria saccifera Gaertn. (1791) (CUVC-67959 to CUVC-67961), Oenocarpus bataua Mart. (1823) (CUVC-67974 to CUVC-67977), Oenocarpus sp. (CUVC-67982 to CUVC-67985), Pholidostachys dactyloides H. E. Moore (1967) (CUVC-67978 to CUVC-67981), Wettinia quinaria (O. F. Cook \& Doyle) Burret (1930) (CUVC-
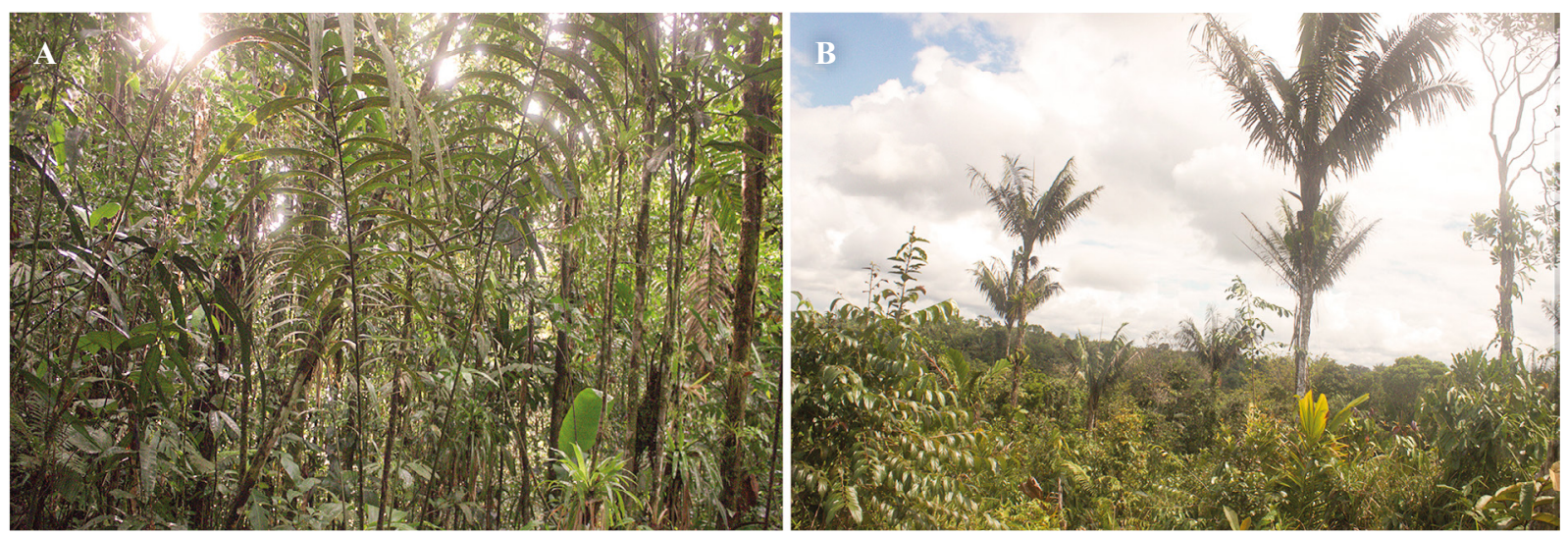

Figure 1. Characteristic habitats at studied sampling sites in rural areas of Buenaventura, Valle del Cauca, Colombia: A. Secondary forest. B. Disturbed areas. 


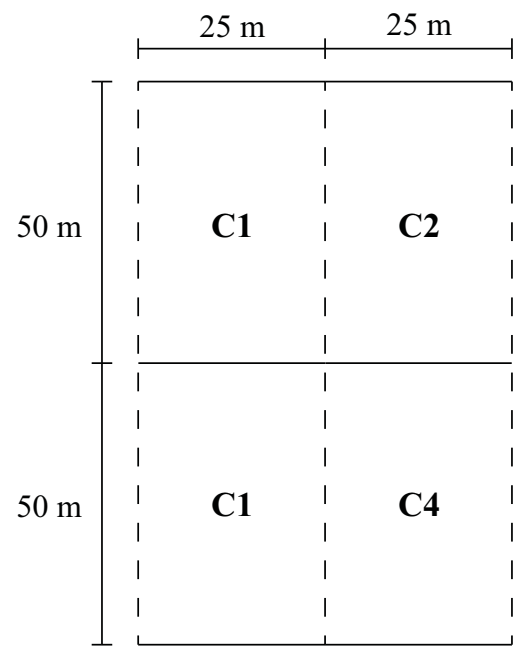

Figure 2. Organization of one of the 36 sampling plots (three at each sampling site): C1, C2, C3 and C4 are Cell 1,2,3, and 4, respectively.

67966 to CUVC-67969) and Wettinia radiata (O. F. Cook \& Doyle) R. Bernal (1995) (CUVC-67970 to CUVC-67973).

Adult and larvae weevil were identified based on Wattanapongsiri (1966). All material was examined at the "Laboratorio de Biología, Ecología y Evolución de Artrópodos", Universidad del Valle, and deposited at the "Museo de Entomología de la Universidad del Valle" (MUSENUV) under the following voucher codes: D. borassi (MUSENUV-29193, MUSENUV-29193-1 and MUSENUV-29193-2).

Data analyses. A Generalized Mixed Linear Model with binomial error distribution was made to assess the differences in the proportion of palms and inflorescences of $O$. bataua in both in zones and in the sampled habitats. All statistical analyses were carried out using the $\mathrm{R}$ version 3.1.5 free distribution program (Core Team 2018) and the Ime4 package to adjust Mixed Effect Generalized Linear Models. Level of significance was $5 \%$.

\section{Results}

A total of twelve species of palms were identified at the study area (including the two zones) and a total of 772 unopened inflorescences were collected (Table 2).

Table 2. Number of unopened inflorescences per palm species collected in Zone A ("Corregimientos" 1 and 2) and Zone B ("Corregimientos" 7 and 8) in Buenaventura, Valle del Cauca, Colombia.

\begin{tabular}{lcc}
\hline \multirow{2}{*}{\multicolumn{1}{c}{ Species }} & \multicolumn{2}{c}{$\begin{array}{c}\text { Number of unopened } \\
\text { inflorescences }\end{array}$} \\
\cline { 2 - 3 } & Zone A & Zone B \\
\hline Attalea allenii H. E. Moore. (1949) & 0 & 3 \\
Bactris coloradonis & 3 & 1 \\
Euterpe precatoria & 7 & 8 \\
Iriartea deltoidea Ruiz y Pav (1798) & 0 & 5 \\
Manicaria saccifera & 45 & 2 \\
Oenocarpus bataua & 63 & 40 \\
Oenocarpus minor & 0 & 2 \\
Oenocarpus sp. & 0 & 1 \\
Pholidostachys dactyloides & 3 & 0 \\
Socratea exorrhiza (Mart.) H. Wendl (1860) & 3 & 15 \\
Wettinia quinaria & 61 & 324 \\
Wettinia radiata & 86 & 100 \\
\hline Total & 271 & 501 \\
\hline
\end{tabular}

Of the twelve palm species identified, damage was only found in O. bataua in both samples (plots and free samples). Complete damage to the inflorescence was observed and more than $50 \%$ of the inflorescences showed various perforations at the apex, the central and basal part of the unopened inflorescences (Figs. 3B-3D). The largest number of perforations was recorded in the central part of the inflorescence in both zones (Zone A: 98 perforations and Zone B: 31 perforations), followed by perforations in the apex ( 35 and 9 , respectively) and the base ( 24 and 8, respectively). The affected bracts (unopened inflorescences) were also totally consumed (rachis, raquilla and flowers) (Fig. 3E). Statistical analyses could not be carried out for this descriptive data because they included observations made by free sampling for which time was not standardized. The pupae were observed at the base of the bracts, each enclosed within a pupal case made from bract fibers (Fig. 3F). For both, the sampling of plots and free sampling, empty pupal cases were found to drop off the inflorescences while the larvae and pupae were found inside. The pupal phase lasted for 40 days until the emergence of the imagoes. Both adult and larvae were identified as D. borassi (Fig. 4).

Some inflorescences with incomplete weevil-induced perforations (13 in Zone A and 5 in Zone B) were observed. A pattern to identify affected inflorescences was determined: whereas healthy inflorescences normally tilt forwards before the bracts open to expose the reproductive structures, damaged unopened inflorescences exhibited a tendency to maintain an upright position.

In plot samplings, the percentage of $O$. bataua affectation was $49.2 \%(62 / 126)$ in Zone A, where six empty pupae and two larvae were found. In Zone B, percentage of affectation was $42.8 \%(21 / 49)$ and five empty pupae were found.

In $O$. bataua free sampling, percentage of palm affectation in Zone A was 47.6 \% (30/63), where five empty pupae, two larvae, and one pupa with a live individual were found. In Zone B, the percentage of affectation was $25 \%(2 / 8)$ and two empty pupae were found (Fig. 5).

No significant statistical differences were found, in terms of damage percentaje, between Zone A and Zone $\mathrm{B}(\mathrm{P}=$ 0.318 ). However, there was a statistically significant effect for habitat $(\mathrm{P}=0.043)$ on the mean proportion of palms affected for $O$. bataua, the effect being greater in the disturbed zone habitat than in the secondary forest (Table 3, Fig. 6A). Regarding affected $O$. bataua bracts, no significant differences were found between Zones A and B $(\mathrm{P}=0.222)$ (Table 3). Nevertheless, a marginal, but statistically negligible, effect was found on comparing habitats (secondary forests vs. disturbed zones) regarding the proportion of affected unopened inflorescences $(\mathrm{P}=0.058)$ (Table 3, Fig. 6B)

\section{Discussion}

Our results showed that, during the season sampled, there was an exclusive association of the weevil D. borassi on $O$. bataua since no attack on the other eleven co-occuring palms in the region was recorded. Although the number of sampled inflorescenses was very different, and there are still uncertainties, our results suggest that $D$. borassi weevils can be host-selective. Their preference for $O$. batatua may be related to a chemical preference for volatile substances produced by this host plant. This behavior was previously reported in literature on other weevils of this subfamily (Reddy and Guerrero 2004; Aldana de la Torre et al. 2011). 

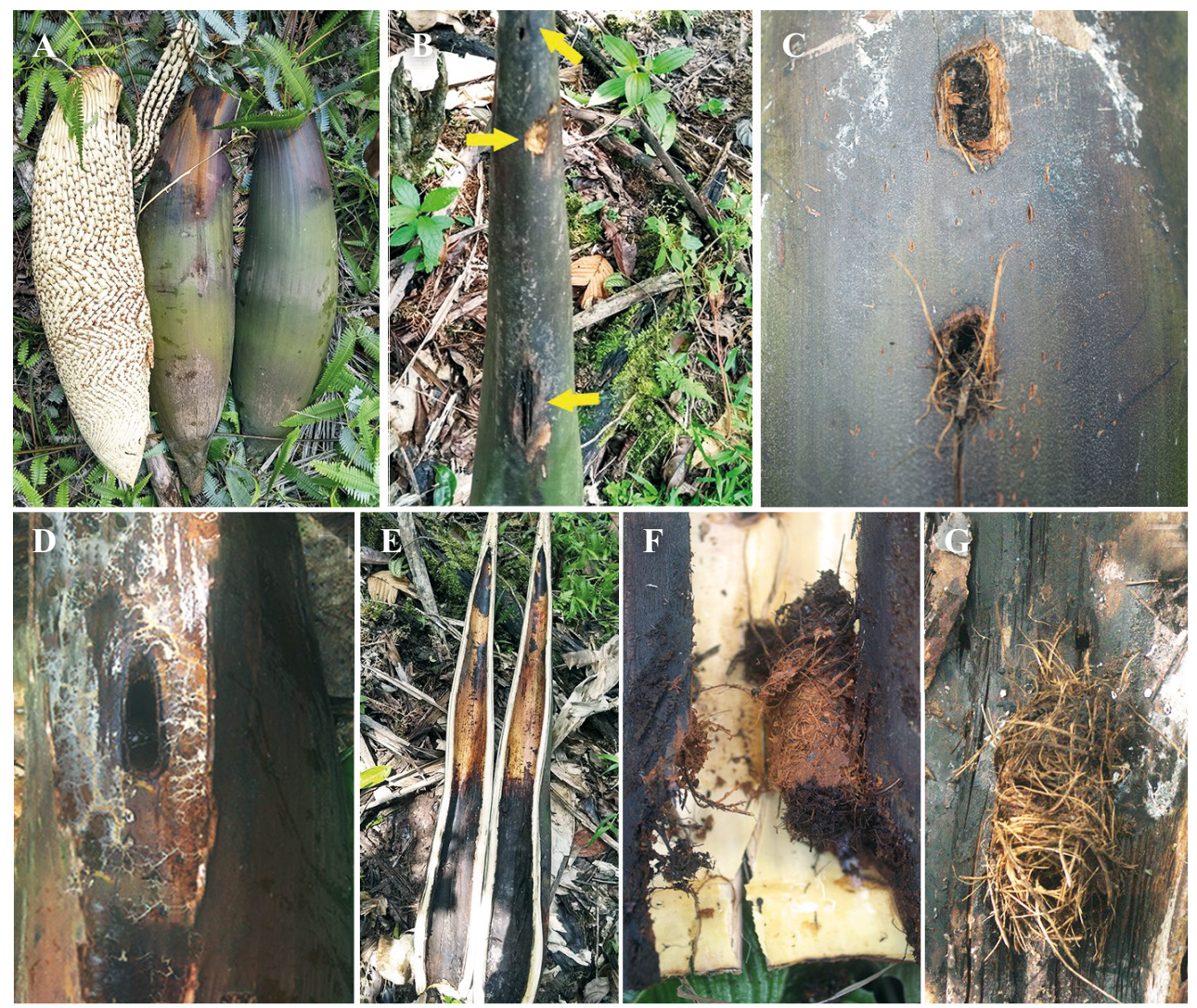

Figure 3. Oenocarpus bataua inflorescences. A. Healthy inflorescence and normal development. B. Damage to the apical portion. C. Damage to the mid-apical portion. D. Damage to the base. E. Completely empty bract affected by the weevil. F. Pupa of Dynamis borassi at the base of the inflorescence. G. Empty D. borassi pupal case.

It is also possible that, due to phenology or other unknown ecological factors, the $D$. borassi would not have attacked other native palm species. Further, it has been shown that it does attack other palms such as peach palm (chontaduro) (Pardo-Locarno et al. 2016) among other palms (Couturier et al. 2000). It seems likely that habitat deterioration and the increase of monocultures in the Pacific region, added to palm deforestation affects peach palm and "milpesos" palm infestation rates.

Our observations also showed that $D$. borassi completes the larval cycle inside $O$. bataua inflorescences. This is consistent with literature reports, which confirm that this species attacks and undergoes its inmature stages in palm inflorescences (Giblin-Davis et al. 1996; Couturier et al. 1998a, 1998b; 2000). A different damage pattern occurs in chontaduro ( $B$. gasipaes or peach palm) crops, where the larva often burrows into the apical portion of the stem to complete its develop- ment (A. A. Vásquez-Ordóñez, pers. obs.). This behavior has also been documented in other palms, such as in O. mapora $\mathrm{H}$. Karst 1857; and it has been found that, on occasions, it only affects the stem, such as in E. oleracea (Beserra et al. 2006).

An important observation for the diagnosis of attack is that affected inflorescences (bracts) remain in an upright position and do not tilt forward, a symptom of great importance for differencial identification when the height of the palm hinders a more detailed diagnosis.

Seventeen (17) empty pupal cases were found in inflorescences: almost half of the inflorescences sampled were found to be damaged and with evidence of insect exit but without insect presence. Up to three individuals in any state of development were found per inflorescence, which means that various individuals can develop in an inflorescence. This also suggests the seasonality of the occurrence of $D$. borassi at our study site, which was reinforced by peach palm (B. gasipaes)
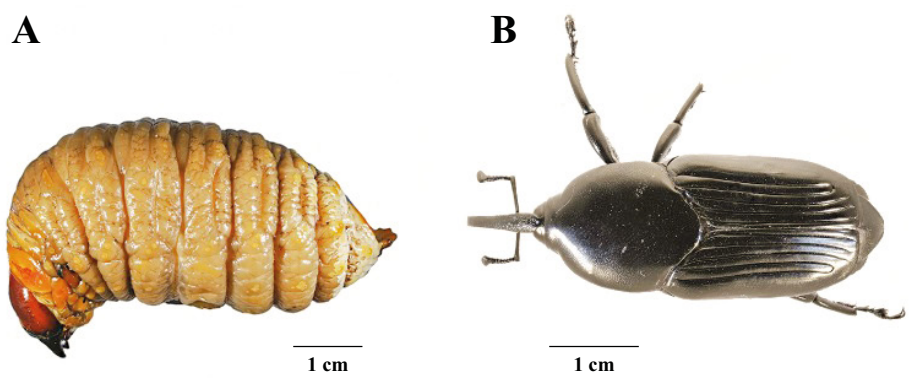

C

Figure 4. Dynamis borassi Olivier (Curculionidae, Dryophthorinae) larva and adult. A. Larva. B. Adult male (dorsal view). C. Adult male (lateral view). 


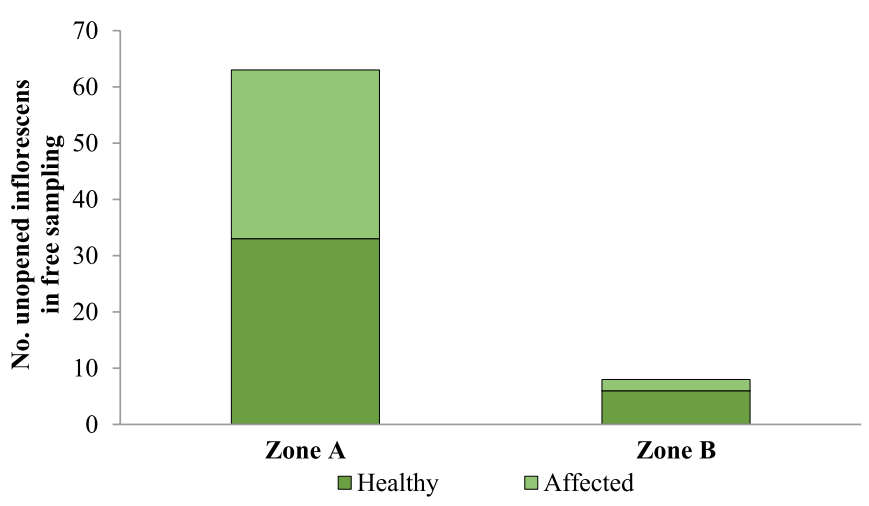

Figure 5. Dynamis borassi attack on developing Oenocarpus bataua inflorescences at Zone A ("corregimientos" 1 and 2) and Zone B ("corregimientos" 7 and 8) in the municipality of Buenaventura, Valle del Cauca, Colombia.

observations near the study sites during the same season that showed a similar seasonal pattern of D. borassi abundance. However, we also found larvae inside inflorescences thus demonstrating the possibility of an asynchronous population cycle. This asynchrony may be related to the variable phenology of the host palm $(O$. bataua $)$ (Nuñez-Avellaneda and Rojas-Robles 2008) that maintains floral resources over the entire year thus allowing the continuous development of $D$. borassi populations. This may also be explained by a multivoltine behavior of this weevil, something which has also been reported for other species of this subfamily (Riba and Alonso 2007). However, more studies on this aspect are needed specifically for $D$. borassi.

Greater affectation of the weevil in O. bataua was observed in disturbed habitats. A possible, yet scientifically unproven, explanation is that weevil populations are directly influenced by the concentration or spatial dispersion of the suitable host palms. In the disturbed habitats and peach palm monocultures, where the palms are more exposed and concentrated, weevils can localize food resources more easily (Root 1973). Instead, when within the forest, the weevil is less likely to easily find its host plant, because there is more vegetation diversity and a greater abundance of plants with different phytochemicals that produce different aromas. This could mask chemical stimuli and physical obstacles (Vandermeer 1989) that act as barriers, thus permitting the insects to infest more plants and inflorescences. Nevertheless, more research is required to confirm this hypothesis and this study does not claim to have found evidence of it.

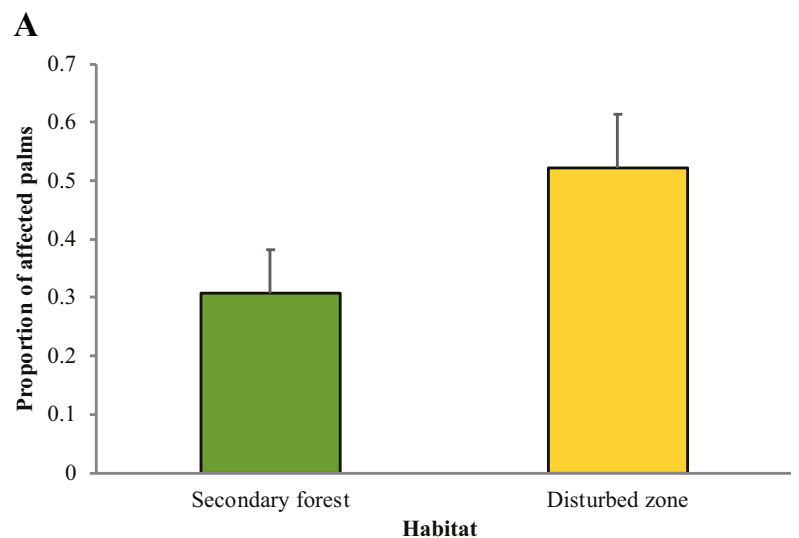

Table 3. Deviation analysis (chi square, $\chi^{2}$; degrees of freedom, Df; and probability, Pr) for two response variables: proportions of affected $O e$ nocarpus bataua individuals and inflorescences in the two sampled areas (Zones A and B); the two sampled habitat types (secondary forest and disturbed site); and zone-habitat interaction in Buenaventura, Valle del Cauca, Colombia.

\begin{tabular}{lcccccc}
\hline \multirow{2}{*}{ Area } & \multicolumn{3}{c}{$\begin{array}{c}\text { Proportion of affected } \\
\text { palms }\end{array}$} & \multicolumn{3}{c}{$\begin{array}{c}\text { Proportion of affected } \\
\text { unopened inflorescences }\end{array}$} \\
\cline { 2 - 7 } & $\chi^{2}$ & Gl & $\operatorname{Pr}\left(>\chi^{2}\right)$ & $\chi^{2}$ & GI & $\operatorname{Pr}\left(>\chi^{2}\right)$ \\
\hline Zone & 0.998 & 1 & 0.318 & 1.489 & 1 & 0.222 \\
Habitat & 4.088 & 1 & $0.043^{*}$ & 3.608 & 1 & 0.058 \\
Zone-Habitat & 2.003 & 1 & 0.157 & 1.536 & 1 & 0.215 \\
\hline
\end{tabular}

\section{Conclusions}

A descriptive and quantitative report on an exclusive $D$. borassi association with the $O$. bataua palm in the tropical region was produced. All damage was reported within unopened inflorescences, where the weevil seems to carry out all immature stages. This is extremely important for understanding the ecology of this weevil in non-cultivated palms and contributes to understanding their impact on peach palm (chontaduro) crops.

Our results suggest that increasing deforestation, particularly of native palms, and replacement of natural forest cover with peach palm monoculture favor the scenario of the agroecological resource concentration hypothesis. Although more research is required, our results present possible explanations and hypotheses for further work. Studies regarding direct temporal relationships between the deforestation of native palms and increased infestation of the peach palm by $D$. borassi, together with plausible reasons behind host preference, should continue. It is also necessary to spatially and temporally increase research, such as that reported for the Colombian Choco, in order to establish associations with other species of native palms.

\section{Acknowledgements}

We thank Colciencias, National Basic Sciences Program, for financing the project under Project Code contract (FP44842428-2017). To the rural communities of "Corregimientos" 1 , 2, 7 and 8 in the municipality of Buenaventura whose support permitted the study to be carried out. To the "Grupo de Investigación en Biología, Ecología y Manejo de Hormigas" and "Grupo de Ecología de Agroecosistemas y Hábitats

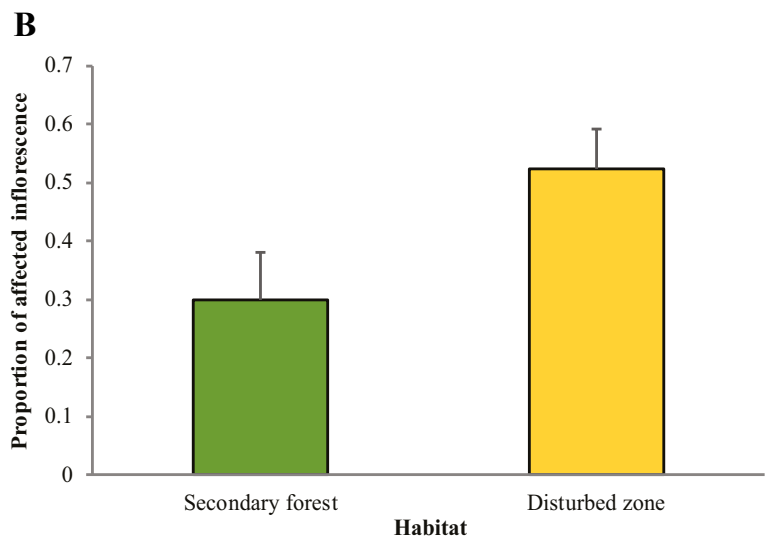

Figure 6. Dynamis borassi damage to Oenocarpus bataua palms (A), and infloresences (B), in secondary forests and disturbed zones in the municipality of Buenaventura on the Colombian Pacific Coast. 
Naturales, GEAHNA" for their support, the use of their facilities and their academic advice. To Wilmar Torres, the Biology Graduate Program statistician at Universidad del Valle for his statistical support. To field assistants "Guineo" (Las Brisas) and Jose (Llano Bajo). To the "Postgrado en Ciencias Biología" at the Universidad del Valle for the laboratory images and photographs of the specimens. To Bernhard Löhr and James Montoya-Lerma for editing the original text and their advice during the project. To Alejandro Zuluaga for aiding in the identification of botanical material. To Luz Amalia Forero and Nelson Albaran for their lodging and support at the "Centro Forestal Pedro Antonio Pineda”, Universidad de Tolima.

\section{Literature cited}

ALCALDÍA DISTRITAL DE BUENAVENTURA. 2015. Análisis de situación de salud, modelo de los determinantes sociales de salud Distrito de Buenaventura. Vigilancia en Salud Pública. Secretaria de Salud Pública. Alcaldía Distrital de Buenaventura, Colombia. 118 p. https://www.minsalud.gov.co/sites/rid/Lists/ BibliotecaDigital/RIDE/VS/ED/PSP/asis-distrital-2015-buenaventura.pdf

ALDANA DE LA TORRE, R. C.; ALDANA DE LA TORRE, J. A.; MOYA,O.M.2011. Manejo del picudo Rhynchophorus palmarum L. (Coleoptera: Curculionidae). Instituto Colombiano Agropecuario (ICA). Bogotá, Colombia. 51 p. https://www.ica.gov.co/ getattachment/19e016c0-0d14-4412-af12-03eecfe398f2/Manejo-del-picudo--Rhynchophorus-palmarum-L--(Cole.aspx

ALTIERI, M. A. 1992. El rol ecológico de la biodiversidad en agroecosistemas. Revista Agroecología y Desarrollo, No 4, CLADES. Santiago, Chile. https://agroabona.files.wordpress.com/2011/01/ el-rol-ecologico-de-la-biodiversidad-en-agroecosistemas.pdf

ANDOW, D. A. 1991. Vegetational diversity and arthropod population response. Annual Review of Entomology 36: 561-586. https://doi.org/10.1146/annurev.en.36.010191.003021

ANGULO, J. A. 2012. La ictiofauna en la cuenca media del río Anchicayá y la identificación de peces nativos promisorios para la acuicultura. Sabia. Universidad del Pacífico. Colombia (1): 8092. http://www.unipacifico.edu.co:8095/unipaportal/sabia.com/ ediciones/1/LAICTIOFAUNA.pdf

ARMBRECHT, I. 2016. Agroecología y biodiversidad. Primera edición. Cali, Valle del Cauca. Editorial Universidad del Valle, Cali, Colombia. $326 \mathrm{p}$.

BENCHIMOL, M.; TALORA, D. C.; MARIANO-NETO, E.; OLIVEIRA, T. L. S.; LEAL, A.; MIELKE, M. S.; FARIA, D. 2017. Losing our palms: The influence of landscape-scale deforestation on Arecaceae diversity in the Atlantic forest. Forest Ecology and Management 384 (15): 314-322. https://doi.org/10.1016/j. foreco.2016.11.014

BERNAL, R.; GALEANO, G. (Eds.). 2013. Cosechar sin destruir: aprovechamiento sostenible de palmas colombianas. Primera edición. Facultad de Ciencias - Instituto de Ciencias Naturales, Universidad Nacional de Colombia. Bogotá, D. C. 244 p. https:// www.academia.edu/35267935/Bernal_and_Galeano_2012_ Cosechar_sin_destruir

BESERRA, P.; COUTURIER, G.; OLIVEIRA, M. D. S. P. 2006. Cultivated açai palm (Euterpe oleracea) and associated weevils: Foveolus maculatus and Dynamis borassi (Coleoptera: Dryophthoridae). Palms 50 (3): 120-122. https://ainfo.cnptia.embrapa. br/digital/bitstream/item/38940/1/SP7174.pdf

BOCANEGRA-GONZÁLEZ, K. T.; FERNÁNDEZ-MÉNDEZ, F.; GALVIS-JIMÉNEZ, J. D. 2015. Grupos funcionales de árboles en bosques secundarios de la región Bajo Calima (Buenaventura, Colombia). Boletín Científico Centro de Museos Museo de Historia Natural 19 (1): 17-40. DOI: 10.17151/bccm.2015.19.1.2 http://190.15.17.25/boletincientifico/downloads/Boletin(19)1_2. pdf
CLEMENT, C. R.; WEBER, J. C.; VAN LEEUWEN, J.; ASTORGA DOMIAN, C.; COLE, D. M.; ARÉVALO LOPEZ, L. A.; ARGÜELLO, H. 2004. Why extensive research and development did not promote use of peach palm fruit in Latin America. Agroforestry Systems 61: 195-206. https://doi.org/10.1023/ B:AGFO.0000028999.84655.17

CONG, W. F.; HOFFLAND, E.; LI, L.; SIX, J.; SUN, J. H.; BAO, X. G.; SHANG, F. S.; VAN DER WERF, W. 2015. Intercropping enhances soil carbon and nitrogen. Global Change Biology 21 (4): 1715-1726. https://doi.org/10.1111/gcb.12738

COUTURIER, G.; O'BRIEN, C. W.; KAHN F. 1998a. Astrocaryum carnosum and $A$. chonta (Palmae), new host for the weevil $D y$ namis borassi (Curculionidae: Rhynchophorinae). Principes 42 (4): 227-228. https://horizon.documentation.ird.fr/exl-doc/ pleins_textes/pleins_textes_6/b_fdi_49-50/010017782.pdf

COUTURIER, G.; OLIVEIRA, M. D. S. P.; BESERRA, P.; KAHN, F. 1998b. A fauna entomológica da bacaby (Oenocarpus mapora Karsten, Palmae) no Estado do Pará. pp. 750. In: XVII Congresso Brasileiro de Entomologia, Rio de Janeiro, VIII Encontro Nacional de Fitossanitaristas. Vol. 2. Brasil. pp. 711-1111. https://ainfo. cnptia.embrapa.br/digital/bitstream/item/100519/1/3396.pdf

COUTURIER, G.; OLIVEIRA, M. D. S. P.; BESERRA, P. 2000. Besouros nocivos à bacabeira: Dynamis borassi e Foveolus aterpes. Embrapa Amazônia Oriental. Comunicado técnico. Brasil. 5 p. https://ainfo.cnptia.embrapa.br/digital/bitstream/item/39861/1/ Com-Tec-19-Am-Oriental.pdf

GAlEANO, G.; BERNAL, R. 2010. Palmas de Colombia. Guía de campo. Primera edición. Editorial Universidad Nacional de Colombia. Bogotá, Colombia. 688 p. https://www.academia. edu/7269300/Bernal_Galeano_2010_GUIA_PALMAS

GERBER, K.; GIBLIN-DAVIS, R. M.; ESCOBAR-GOYES, J. 1990. Association of the red ring nematode, Rhadinaphelenchus cocophilus, with weevils from Ecuador and Trinidad. Nematropica 20 (1): 39-49. https://journals.flvc.org/nematropica/article/ view/63974

GIBLIN-DAVIS, R. M.; OEHLSCHLAGER, A. C.; PEREZ, A.; GRIES, G.; GRIES, R.; WEISSLING, T. J.; CHINCHILLA, C. M.; PEÑA, J. E.; HALLETT, R. H.; PIERCE, H. D.; JR.; GONZALEZ, L. M. 1996. Chemical and behavioral ecology of palm weevils (Curculionidae: Rhynchophorinae). The Florida Entomologist 79 (2): 153-167. https://doi.org/10.2307/3495812

GODOY, S. P.; PENCUE, L.; RUIZ, A.; MONTILLA D. C. 2007. Clasificación automática del chontaduro (Bactris gasipaes) para su aplicación en conserva, mermelada y harinas. Biotecnología en el sector agropecuario y agroindustrial. Revista de la Facultad de Ciencias Agrarias. Universidad del Cauca 5 (2): 137-146. https://revistas.unicauca.edu.co/index.php/biotecnologia/article/ view/669/298

INSTITUTO COLOMBIANO AGROPECUARIO (ICA). 2015. Resolución 1786 de 2015. Instituto Colombiano Agropecuario. https://www.ica.gov.co/getattachment/fcbc4f95-8834-40a1 89b8-374ea4a10154/2015R1-(2).aspx

LETOURNEAU, D. K.; ARMBRECHT, I.; SALGUERO, R. B.; MONTOYA-LERMA, J.; JIMÉNEZ-CARMONA, E.; DAZA, M. C.; ESCOBAR, S.; GALINDO, V.; GUTIERREZ, C.; DUQUE-LÓPEZ, S.; LOPÉZ-MEJÍA, J.; ACOSTA-RANGEL, M. A.; HERRERA-RANGEL, J.; RIVERA, L.; SAAVEDRA, C. A.; TORRES, A. M.; REYES-TRUJILLO, A. 2011. Does plant diversity benefit agroecosystems? A synthetic review. Ecological Applications 21 (1): 9-21. https://doi.org/10.1890/09-2026.1

LINDGREN, J.; LINDBORG, R.; COUSINS, S. A. O. 2018. Local conditions in small habitats and surrounding landscape are important for pollination services, biological pest control and seed predation. Agriculture, Ecosystems \& Environment 251 (1): 107-113. https://doi.org/10.1016/j.agee.2017.09.025

MORA-URPÍ, J.;WEBER, J. C.; CLEMENT, C. R. 1997. Peach palm. Bactris gasipaes Kunth. Promoting the conservation and use of underutilized and neglected crops. 20. Institute of Plant Genetics and Crop Plant Research, Gatersleben/ International Plant Ge- 
netic Resources Institute, Rome, Italy. 83 p. https://www.google. com/url? sa $=$ t\&rct $=$ j\&q $=\&$ esrc $=$ s\& source $=$ web\&cd $=\& v e d=2 a-$ hUKEwjUxOvuz9LsAhWho1kKHST1Aw4QFjAAegQIBhAC\&url=http $\% 3 \mathrm{~A} \% 2 \mathrm{~F} \% 2 \mathrm{Fwww}$. worldagroforestry. org\%2Fdownloads\%2Fpublications\%2FPDFs\%2Fb10186.pdf\&usg=AOvVaw1EQsVj9e5mrnQeVbhkOj_a

NAVARRO, J. A. 2015. Dinámica poblacional de tres palmas utilizadas en construcción (Lepidocaryum tenue, Socratea exorrhi$z a$ e Iriartea deltoidea): alternativas para su manejo sostenible en la Amazonia colombiana. Tesis doctor en Ciencias-Biología. Facultad de Ciencias. Universidad Nacional de Colombia. 167 p. http://bdigital.unal.edu.co/52235/1/Tesis\%20de\%20Doctorado\%20Jaime\%20Navarro.pdf

NUÑEZ-AVELLANEDA, L. A.; ROJAS-ROBLES, R. 2008. Biología reproductiva y ecología de la polinización de la palma milpesos Oenocarpus bataua en los andes colombianos. Caldasia 30 (1): 101-125. https://revistas.unal.edu.co/index.php/cal/article/ view/39132

ORDOÑEZ-SANTOS, L. E.; PINZÓN-ZARATE, L. X.; GONZÁLEZ-SALCEDO, L. O. 2015. Optimization of ultrasonic-assisted extraction of total carotenoids from peach palm fruit (Bactris gasipaes) by-products with sunflower oil using response surface methodology. Ultrasonics Sonochemistry 27: 560-566. https:// doi.org/10.1016/j.ultsonch.2015.04.010

PAGÁN, I.; GONZÁLEZ-JARA, P.; MORENO-LETELIER, A.; RODELO-URREGO, M.; FRAILE, A.; PIÑERO, D.; GARCÍA-ARENAL, F. 2012. Effect of biodiversity changes in disease risk: Exploring disease emergence in a plant-virus system. PLoS Pathogens 8 (7): 1-12. https://doi.org/10.1371/journal. ppat. 1002796

PALOMO-CAMPESINO, S.; GONZÁLEZ, J. A.; GARCÍA-LLORENTE, M. 2018. Exploring the connections between agroecological practices and ecosystem services: A systematic literature review. Sustainability 10: 2-21. https://doi.org/10.3390/ su10124339

PARDO-LOCARNO, L. C. 2016. Avances en el diagnóstico fitosanitario del cultivo de chontaduro en la zona rural de Buenaventura, Valle. Revista Científica Sabia. Universidad del Pacífico. Buenaventura, Colombia 1 (3): 39-53. http://www.unipacifico. edu.co:8095/publicacionesunipa/documentos/art_sb3 4.pdf

PARDO-LOCARNO, L. C.; CONSTANTINO, L. M.; AGUDELO, R.; ALARCÓN, A.; CAICEDO, V. 2005. Observaciones sobre el gualapán (Coleoptera: Chrysomelidae: Hispinae) y otras limitantes entomológicas en cultivos de chontaduro en el Bajo Anchicayá. Acta Agronómica 54 (2): 25-30. https://revistas.unal.edu.co/ index.php/acta agronomica/article/view/109

PERFECTO, I.; VANNDERMEER, J.; WRIGHT, A. 2009. Nature's matrix: linking agriculture, conservation and food sovereignty.
First Edition. Londres. Inglaterra. Dunstan House. 242 p. https:// doi.org/10.4324/9781849770132

R CORE TEAM. 2018. R: Un lenguaje y entorno para la informática estadística. Fundación R de Computación Estadística, Viena.

REDDY, G. V. P.; GUERRERO, A. 2004. Interactions of insect pheromones and plant semiochemicals. Trends in Plants Science 9 (5): 253-261. https://doi.org/10.1016/j.tplants.2004.03.009

RIBA, J. M.; ALONSO, M. A. 2007. El picudo negro de la pita o agave, o max del henequén, Scyphophorus acupunctatus Gyllenhal, 1838 (Coleoptera: Dryophthoridae): primera cita para la península Iberica. Boletín Sociedad Entomológica Aragonesa 41: 419-422. http://sea-entomologia.org/Publicaciones/PDF/ BOLN41/419 422_BSEA_41_Scyphophus.pdf

ROOT, R. B. 1973. Organization of a plant-arthropod association in simple and diverse habitats: the fauna of collards (Brassica oleracea). Ecological Monographs 43 (1): 95-124. https://doi. org/10.2307/1942161

STEHR, F. W. 1987. Immature insects. Vol. 1. Kendall/Hunt, Dubuque, Iowa, EE. UU. 754 p.

VANDERMEER, J. H. 1989. The ecology of intercropping. Cambridge University Press. Cambridge, Reino Unido. 237 p. https:// doi.org/10.1017/CBO9780511623523

WATTANAPONGSIRI, A. 1966. A revision of the genera Rhynchophorus and Dynamis (Coleoptera: Curculionidae). Thesis (Ph. D.). Oregon State University. Oregon, EE. UU. 418 p. https:// ir.library.oregonstate.edu/concern/graduate_thesis_or_dissertations/6d570047d

ZHAO, J.; WAN, S.; LI, Z.; SHAO, Y.; XU, G.; LIU, Z.; ZHOU, L.; FU, S. 2012. Dicranopteris-dominated understory as major driver of intensive forest ecosystem in humid subtropical and tropical region. Soil Biology \& Biochemistry 49: 78-87. https:// doi.org/10.1016/j.soilbio.2012.02.020

\section{Origin and funding}

Project origin title: "Diagnóstico fitosanitano y estrategias de manejo de las muertes masivas de palmas de chontaduro (Bactris gasipaes, Arecaceae) en Colombia." funded by Programa Nacional de Ciencias Básicas, Colciencias code: 110677657123.

\section{Author contribution}

Maria Alejandra Bautista-Giraldo: $35 \%$, inspiration, design, field work, data analyses, literature, writting.

Inge Armbrecht: $30 \%$, inspiration, design, data analyses, literature, writting.

Aymer Andrés Vásquez-Ordoñez: $35 \%$, inspiration, design, field work, data analyses, literature, writting. 